\title{
Preparation and Study of the Effect of Annealing Temperature on the Structural, Optical, and Morphological Properties of Nanocrystalline $\mathrm{SnO}_{2}$ Doped with $\mathrm{Cu}$
}

\author{
Nada K. Abass*, Duha S. Shaker \\ Physics Department, College of Science for Women, University of Baghdad - Iraq
}

\section{Article information}

Article history:

Received: August, 11, 2021

Accepted: September, 07, 2021

Available online: October, 20, 2021

\section{Keywords:}

$\mathrm{Cu}$ doped tin oxide,

Spray pyrolysis,

Absorption coefficient,

Transmittance

\section{*Corresponding Author:}

Nada K. Abass

nadaka_phys@csw.uobaghdad.edu.iq

DOI:

https://doi.org/10.53523/ijoirVol8I2ID64

\begin{abstract}
In this study, pure $\mathrm{SnO}_{2}$ nanocrystalline films were doped with copper using the spray pyrolysis technique. $\mathrm{SnCl}_{2} .2 \mathrm{H}_{2} \mathrm{O}, \mathrm{CuCl}_{2} .2 \mathrm{H}_{2} \mathrm{O}$ were used as precursors. The preparation was done in the form of nanoparticles by chemical precipitation method. The prepared materials were annealed at $300^{\circ} \mathrm{C}$ and $500^{\circ} \mathrm{C}$ for $1 \mathrm{~h}$ to improve crystallization. XRD results of the samples prepared by spray pyrolysis of a solution containing nanoparticles showed that the samples were crystallized in the rutile tetragonal phase. The average crystal size of $\mathrm{SnO}_{2}$ annealed at $300^{\circ} \mathrm{C}$ is 3.36 and $3.37 \mathrm{~nm}$ for pure and doped samples, respectively, and it is $4.1 \mathrm{~nm}$ and $9.75 \mathrm{~nm}$ for pure and doped annealed at $500^{\circ} \mathrm{C}$, respectively. It is noticed that the crystal structure of $\mathrm{SnO}_{2}$ does not change with the addition of copper, and the studies of Field Emission Scanning Electron Microscopy confirmed the results where the grain size was within the range (20-50) $\mathrm{nm}$, and the thickness of the films obtained from this assay was in the range (0.91.15) $\mu \mathrm{m}$, with the thickness of doped films at $500^{\circ} \mathrm{C}$ are higher than those at $300^{\circ} \mathrm{C}$. The Atomic Force Microscopy results showed that the roughness rate of the pure films annealed at $300^{\circ} \mathrm{C}$ and $500^{\circ} \mathrm{C}$ is 7.99 and $17.4 \mathrm{~nm}$, respectively, while roughness for doped annealed samples were 9.09 and $7.12 \mathrm{~nm}$, respectively. The optical results obtained from UV-Vis analysis showed that the optical bandgap at $300^{\circ} \mathrm{C}$ for pure and doped samples was (3.40 and 2.8) eV, respectively, while it was (3.75 and 2.59$) \mathrm{eV}$ at $500^{\circ} \mathrm{C}$ for pure and doped samples, respectively. The transmittance decreases with increasing annealing temperature, because the absorbance increases. The extinction coefficient increases, while refractive index decreases with increasing annealing temperature. The absorbance was 0.94 and 1.17 for pure and doped samples at $300^{\circ} \mathrm{C}$, and was 1.16 and 1.46 at $500^{\circ} \mathrm{C}$.
\end{abstract}

\section{Introduction}

Researchers focused on the study of semiconductors in the early nineteenth century, because these materials have impressive properties, such as conductivity change with heat, light, and magnetic fields. The properties of 
semiconductor materials have played a significant role in technological applications [1]. Solid crystalline materials are divided according to their ability to conduct electricity into conductors, insulators, and semiconductors (and this classification is based on the energy gap). At absolute zero (0K), semiconducting materials are completely insulators with no electrical conductivity, and as the temperature rises, the electrical conductivity of the materials increases, and it is one of the important characteristics that are used in various technological applications [2]. According to literature, $\mathrm{SnO}_{2}$ nanofilms belong to a class of materials that combine high optical transparency with good electrical conductivity [3]. Tin oxide is a crystalline solid with a rutile tetragonal structure. It has a large bandgap. n-type in nature with non-stoichiometric structure. The conductivity of $\mathrm{SnO}_{2}$ thin films can be changed to the best with appropriate dopants [4]. Doped $\mathrm{SnO}_{2}$ thin films have a bulk energy bandgap of $3.6 \mathrm{eV}[5,6,7]$. These properties make $\mathrm{SnO}_{2}$ thin films suitable for a variety of applications in many fields of research and device fabrication. The thin-film applications in environmental monitoring through gas sensing is the most essential. $\mathrm{SnO}_{2}$ properties for gas sensing applications have been improved through catalytic and impurity doping to improve performance $[8,9]$.

Many methods have been used to deposit $\mathrm{SnO}_{2}$ based thin films, including RF magnetron sputtering [10], chemical vapor deposition [11], electron beam evaporation [12], flash evaporation [13], dip coating [14], and spray pyrolysis [15]. Spray pyrolysis was chosen for this study because it allows a good control on the grain size and on the atomic-scale growth by varying the precursor content, the temperature of the substrate, and the pressure of the carrier gas [16]. Furthermore, spray pyrolysis technique is inexpensive and effective for large area coating, and it has a good reproducibility; as a result, the method can be used for the production of highquality thin films on a large scale [17]. In this research, we will prepare nanostructures of $\mathrm{SnO}_{2}$ and study its physical properties, and then study the effect of doping with copper in different proportions, and choose the best doping ratio that gives the best properties of the prepared material, and study the effect of annealing on it for the possibility of using it in various electronic applications such as solar cells and gas sensors.

\section{Experimental Procedure}

$\mathrm{SnCl}_{2} .2 \mathrm{H}_{2} \mathrm{O}, \mathrm{CuCl}_{2} .2 \mathrm{H}_{2} \mathrm{O}$, Triton $\mathrm{X}-100$ as a surfactant, ammonia as a precipitant were used to prepare pure and $\mathrm{Cu}$ doped tin oxide nanoparticles, which are used to prepare nano-thin films.

\section{Preparation of Pure and Cu Doped Tin Oxide Thin Film}

Spray Pyrolysis technique was used to deposit nano-thin films from $\mathrm{SnO}_{2}$ because it is a simple technique and contains low-cost equipment. The thickness of the films can be controlled by changing the spray coefficients. A solution containing $0.5 \mathrm{M}$ of $\mathrm{SnCl}_{2} .2 \mathrm{H}_{2} \mathrm{O}$ dissolved in $50 \mathrm{ml}$ of deionized water and mixed with Triton X-100 surfactant at a rate of 0.05 mland ammonia of $\mathrm{pH}=8$ were mixed. Before spraying the solution, the substrate slides were thoroughly cleaned by ultrasonic bath, followed by ethanol and acetone, then dried well before cutting into $2.5 \mathrm{~cm} \times 2.5 \mathrm{~cm}$ dimensions. After substrate preparation, it was placed onto the electric heater of the spray pyrolysis system, then left for $1 \mathrm{~h}$ to reach the required temperature for the substrate $\left(400^{\circ} \mathrm{C}\right)$. The prepared solution is sprayed onto the substrate using a spraying device, where the distance between the nozzle and the substrate must be taken into account $(30 \pm 1) \mathrm{cm}$ ), the spray time is $5 \mathrm{~s}$, with a stopping time of $55 \mathrm{~s}$. The spray rate is $3 \mathrm{ml} / \mathrm{min}$, and the air pressure is $3.5 \mathrm{bar}$, the substrate temperature is $400^{\circ} \mathrm{C}$. After spraying the solution on the slides, the process was repeated several times. Afterward, the electric heater was turned off and the slides were left to cool down to room temperature. In the same way, the solution was prepared, but by adding $\mathrm{CuCl}_{2} .2 \mathrm{H}_{2} \mathrm{O}$ at a ratio of $2 \%$ wt, and then the solution was sprayed on the slides several times. After the slides cooled, they were annealed at $300^{\circ} \mathrm{C}$ and at $500^{\circ} \mathrm{C}$ for $1 \mathrm{~h}$. Thus, pure $\mathrm{SnO}_{2}$ and $\mathrm{SnO}_{2}: \mathrm{Cu}$ nano-films were obtained.

\section{Characterization}

The X-ray diffraction (XRD) pattern of tin oxide nanoparticles was recorded and compared with the standard Card No.96-900-9083 using $\mathrm{CuK} \alpha, \lambda=0.154 \mathrm{~nm}$. The particle morphology and size were examined by scanning electron microscopy (SEM) ZEISS model SigmaVP with a magnification of 50.00KX and (EDX) Oxford instruments in the UK. Optical properties were analyzed using ultraviolet diffusion. Reflection Spectroscopy was performed using UV-VIS (Shimadzu) within the wavelength range of $280 \mathrm{~nm}-900 \mathrm{~nm}$. AFM was utilized to examine the surface morphology of $\mathrm{SnO}_{2}$ nanocrystalline thin films. The average grain size was calculated using the cumulative distribution plot. 


\section{Results and Discussion}

\section{XRD Analysis}

The significance of this measurement is to know the crystal structure of the materials, indicating the phases of the precipitated materials, and hence the arrangement of the atoms in them and their orientation. The results of the X-ray diffraction examination of the prepared $\mathrm{SnO}_{2}$ nanoscale films is shown in Figure (1). The figure shows that $\mathrm{SnO}_{2}$ thin film has a tetragonal type polycrystalline structure for both pure and $2 \%$ doped with $\mathrm{Cu}$, where the atomic growth was shown by the dominant crystalline trends (110), (101), (211) and that the prevailing trend is (110) consistent with the Karthick et. al. [18]. We can observe some changes in the intensity of the diffraction peaks for some levels after deflection. The peak intensity of doped films is greater than that of pure films, which means that $\mathrm{Cu}$ and $\mathrm{SnO}_{2}$ atoms scatter the X-rays falling on them in the same phase, where the intensity of the peaks decreased, The FWHM value decreases, as well with doping. The crystal size increased according to Scherrer equation [19].

$$
D=K \lambda / \beta \cos \theta
$$

where, $\beta$ : is Full Width at half Maximum, $\theta$ : is Bragg's angle, and $\mathrm{K}=0.9$. At $300^{\circ} \mathrm{C}$ annealing temperture, the films exhibit less crystallinity than those annealed at $500^{\circ} \mathrm{C}$, because the thermal treatment increases the crystallization regularity, which means that the crystallization of the film material increases and the crystalline defects decrease at $500^{\circ} \mathrm{C}$. As well as, the particles become less agglomerated and the atoms are evenly distributed on the sample's surface. At $500^{\circ} \mathrm{C}$ annealing, the crystal size becomes larger. Tables $(1 \& 2)$ show a direct relationship between the temperature of annealing and the size of the nanoparticles [20, 21]. The rise in crystallinity leads to an improvement in the crystal structure. Thus, there are additional peaks that are not present at $300^{\circ} \mathrm{C}$. At $500^{\circ} \mathrm{C}, 2 \theta$ peaks $=26.56^{\circ}, 34.05^{\circ}, 38^{\circ}, 51.83^{\circ}, 54.75^{\circ}$, and $62^{\circ}$ appeared for the hkl (110), (101), (200), (211), (220), and (310), respectively as shown in Figure (2). Therefore, crystallization of the material increases with the increase in roughness.

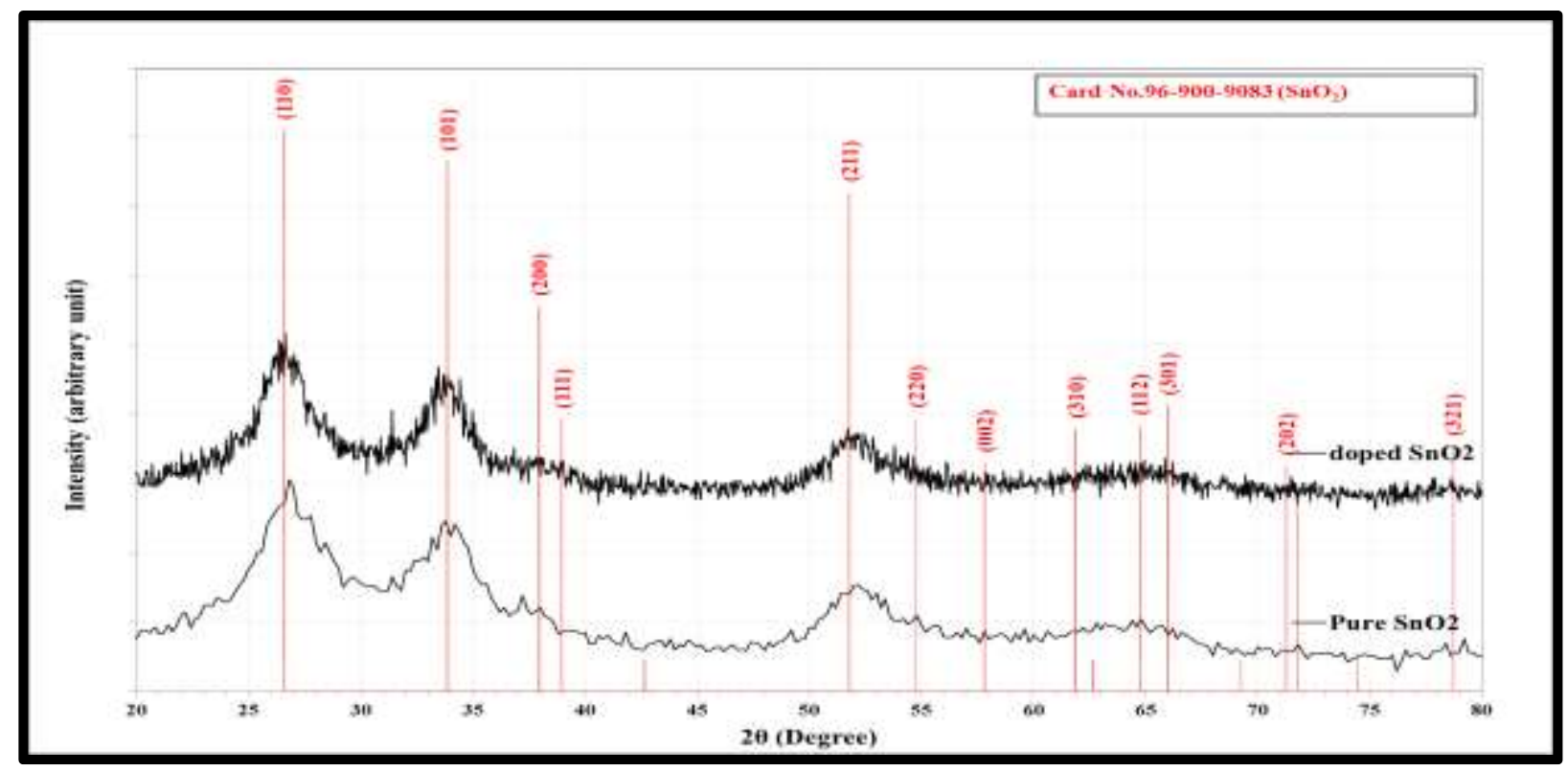

Figure (1). X-ray diffraction pattern of pure $\mathrm{SnO}_{2} \& 2 \%$ wt doped $\mathrm{SnO}_{2}: \mathrm{Cu}$ nanofilm by $\mathrm{SPM}$ for annealing temperature of $300^{\circ} \mathrm{C}$. 
NANO 2021

Special Issue

Iraqi Journal of Industrial Research, Vol. 8, No. 2 (2021)

Table (1). XRD Pattern of $\mathrm{SnO}_{2}$ and $2 \%$ wt $\mathrm{SnO}_{2}: \mathrm{Cu}$ nano films by SPM for annealing temperature of $300^{\circ} \mathrm{C}$.

\begin{tabular}{|c|c|c|c|c|c|c|c|c|}
\hline Sample & $\begin{array}{c}\mathbf{2 \theta} \\
(\mathbf{D e g} .)\end{array}$ & $\begin{array}{c}\text { FWHM } \\
(\mathbf{D e g} .)\end{array}$ & $\begin{array}{c}\text { dhkl } \\
\text { Exp. }(\mathbf{\AA})\end{array}$ & $\mathbf{G . S}(\mathbf{n m})$ & hkl & $\begin{array}{c}\text { dhkl } \\
\text { Std. }(\stackrel{\circ}{\mathbf{A}})\end{array}$ & Phase & Card No. \\
\hline \multirow{3}{*}{ Pure } & 26.8671 & 2.6770 & 3.3157 & 3.1 & $(110)$ & 3.3498 & $\mathrm{SnO}_{2}$ & $96-900-9083$ \\
\cline { 2 - 9 } & 33.8506 & 2.2114 & 2.6459 & 3.8 & $(101)$ & 2.6439 & $\mathrm{SnO}_{2}$ & $96-900-9083$ \\
\cline { 2 - 9 } & 52.1242 & 2.7353 & 1.7533 & 3.2 & $(211)$ & 1.7642 & $\mathrm{SnO}_{2}$ & $96-900-9083$ \\
\hline \multirow{3}{*}{ Doped } & 26.5761 & 2.3279 & 3.3514 & 3.5 & $(110)$ & 3.3498 & $\mathrm{SnO}_{2}$ & $96-900-9083$ \\
\cline { 2 - 9 } & 33.7342 & 1.9787 & 2.6548 & 4.2 & $(101)$ & 2.6439 & $\mathrm{SnO}_{2}$ & $96-900-9083$ \\
\cline { 2 - 9 } & 51.8914 & 2.5606 & 1.7606 & 3.5 & $(211)$ & 1.7642 & $\mathrm{SnO}_{2}$ & $96-900-9083$ \\
\hline
\end{tabular}

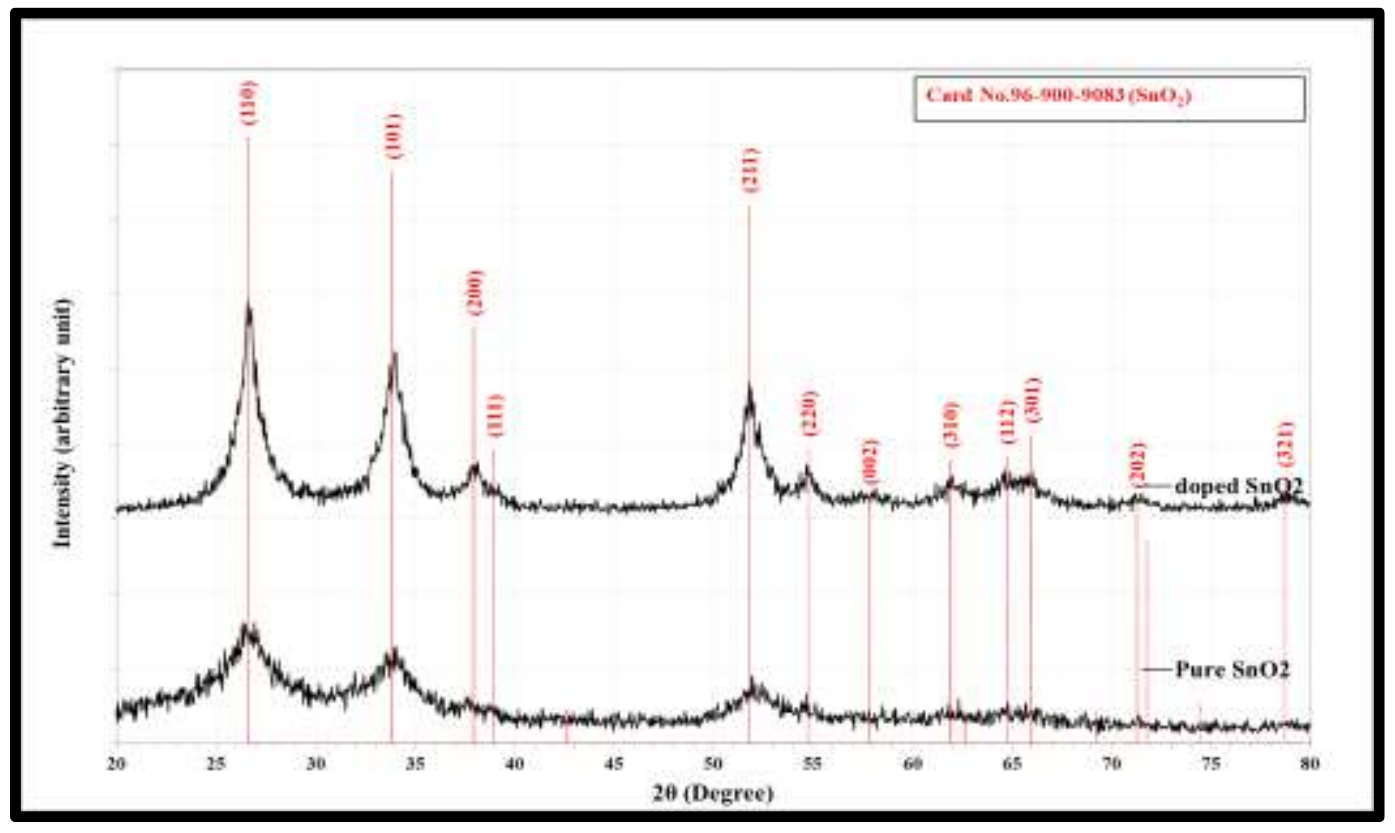

Figure (2). X-ray diffraction pattern of pure $\mathrm{SnO}_{2}$ \& 2\%wt $\mathrm{SnO}_{2}: \mathrm{Cu}$ nanofilms by $\mathrm{SPM}$ for annealing temperature of $500^{\circ} \mathrm{C}$.

Table (2). XRD Pattern of $\mathrm{SnO}_{2}$ and 2\%wt $\mathrm{SnO}_{2}: \mathrm{Cu}$ nanofilms by $\mathrm{SPM}$ for annealing temperature of $500^{\circ} \mathrm{C}$.

\begin{tabular}{|c|c|c|c|c|c|c|c|c|}
\hline Sample & $\begin{array}{c}2 \theta \\
\text { (Deg.) }\end{array}$ & $\begin{array}{c}\text { FWHM } \\
\text { (Deg.) }\end{array}$ & $\begin{array}{r}\text { dhkl } \\
\text { Exp. }(\AA)\end{array}$ & $\begin{array}{l}\text { G.S } \\
(\mathbf{n m})\end{array}$ & hkl & $\begin{array}{c}\text { dhkl } \\
\text { Std.(£) }\end{array}$ & Phase & Card No. \\
\hline \multirow{3}{*}{ Pure } & 26.5907 & 2.1450 & 3.3496 & 3.8 & $(110)$ & 3.3498 & $\mathrm{SnO}_{2}$ & 96-900-9083 \\
\hline & 33.9275 & 2.0518 & 2.6401 & 4.0 & (101) & 2.6439 & $\mathrm{SnO}_{2}$ & 96-900-9083 \\
\hline & 52.0207 & 1.9586 & 1.7565 & 4.5 & (211) & 1.7642 & $\mathrm{SnO}_{2}$ & 96-900-9083 \\
\hline \multirow{6}{*}{ Doped } & 26.6528 & 0.9948 & 3.3419 & 8.2 & (110) & 3.3498 & $\mathrm{SnO}_{2}$ & 96-900-9083 \\
\hline & 34.0518 & 1.0259 & 2.6308 & 8.1 & (101) & 2.6439 & $\mathrm{SnO}_{2}$ & 96-900-9083 \\
\hline & 38.0000 & 0.9327 & 2.3660 & 9.0 & (200) & 2.3686 & $\mathrm{SnO}_{2}$ & 96-900-9083 \\
\hline & 51.8342 & 0.9637 & 1.7624 & 9.2 & (211) & 1.7642 & $\mathrm{SnO}_{2}$ & 96-900-9083 \\
\hline & 54.7565 & 0.7150 & 1.6751 & 12.5 & $(220)$ & 1.6749 & $\mathrm{SnO}_{2}$ & $96-900-9083$ \\
\hline & 62.0000 & 0.8083 & 1.4956 & 11.5 & (130) & 1.4981 & $\mathrm{SnO}_{2}$ & 96-900-9083 \\
\hline
\end{tabular}




\section{Energy Dispersive X-ray Spectroscopy (EDX)}

The EDX results show that the fabricated samples are $\mathrm{SnO}_{2}$ and $\mathrm{SnO}_{2}: \mathrm{Cu}$, as shown in Figure (3). The quantity of element growth on the sample is shown in Table (3), which includes copper $(\mathrm{Cu})$, tin $(\mathrm{Sn})$, and oxygen $(\mathrm{O})$. Copper functions as a dopant in tin oxide, affecting the sample's transparency and sheet resistance.

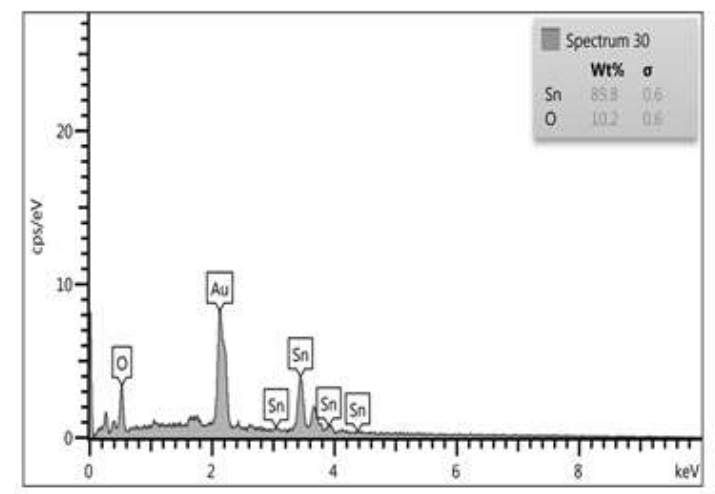

(A)

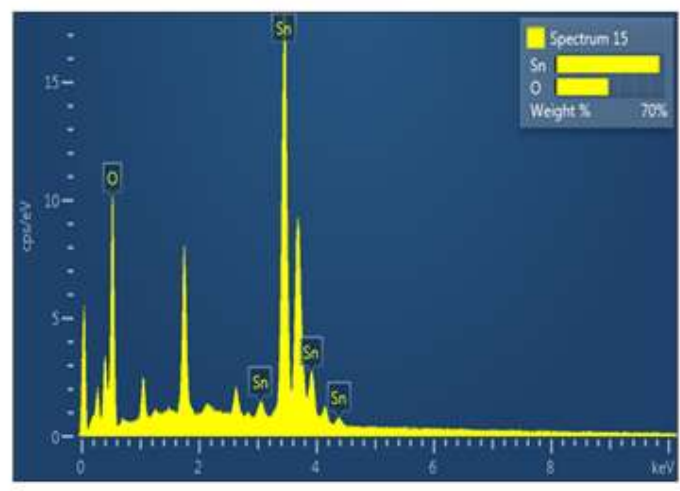

(C)

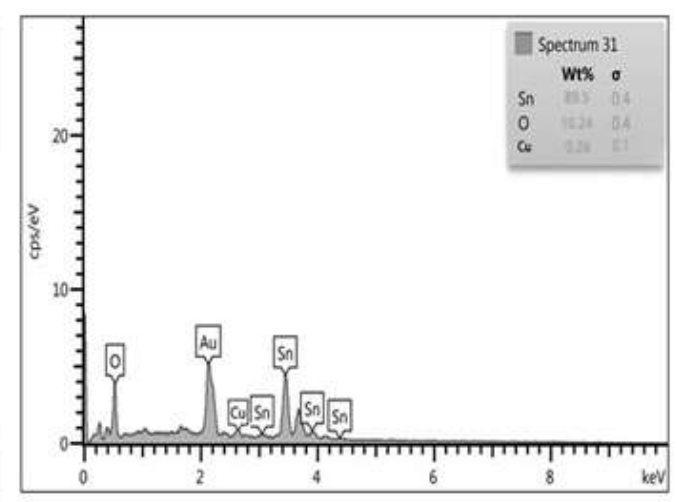

(B)

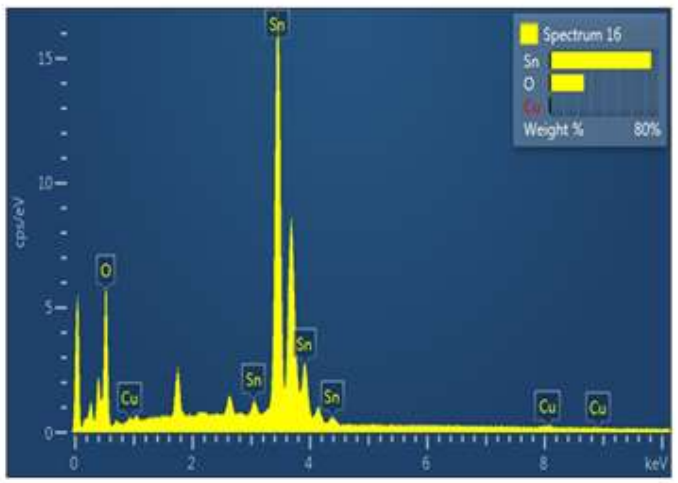

(D)

Figure (3). EDX image of (A): pure $\mathrm{SnO}_{2}$ nanocrystalline at $300^{\circ} \mathrm{C},(\mathrm{B}): \mathrm{SnO}_{2}: \mathrm{Cu}$ at $300^{\circ} \mathrm{C}$, (C) pure $\mathrm{SnO}_{2}$ at $500^{\circ} \mathrm{C}$, and (D) $\mathrm{SnO}_{2}: \mathrm{Cu}$ at $500^{\circ} \mathrm{C}$.

Table (3). The actual composition of the rated EDX prepared materials are scheduled by spray pyrolysis method.

\begin{tabular}{|c|c|c|c|c|}
\hline $\begin{array}{c}\text { EDX } \\
\text { Composition }\end{array}$ & Temperature & Sn (wt\%) & O (wt\%) & Cu (wt\%) \\
\hline Pure & $300^{\circ} \mathrm{C}$ & 89.4 & 8.9 & 0 \\
\hline $\mathbf{2 \%} \mathbf{C u}$ & $300^{\circ} \mathrm{C}$ & 82.1 & 5.6 & 0.5 \\
\hline Pure & $500^{\circ} \mathrm{C}$ & 66.18 & 33.82 & 0 \\
\hline $\mathbf{2 \%} \mathbf{C u}$ & $500^{\circ} \mathrm{C}$ & 74.46 & 25.16 & 0.38 \\
\hline
\end{tabular}

\section{Atomic Force Microscopy (AFM) for Pure $\mathrm{SnO}_{2} \mathrm{Cu}$ Doped $\mathrm{SnO}_{2}$ Prepared by Spray Pyrolysis Method}

The 2D and 3D images show that the $\mathrm{SnO}_{2}$ topography for all samples has spherical shapes as shown in Figure (4). Moreover, in the area that has been investigated by AFM, it is found that the roughness average of pure $\mathrm{SnO}_{2} \mathrm{NPS}$ and $\mathrm{SnO}_{2}: \mathrm{Cu}$ at $300^{\circ} \mathrm{C}$ annealing are $7.99 \mathrm{~nm}$ and $9.09 \mathrm{~nm}$, while the grain size is $56.36 \mathrm{~nm}$ and 71.49 $\mathrm{nm}$, respectively. Where the grain size increased in doped samples because crystallinity defects occurred, which leads to an increase in the size due to the addition of $\mathrm{Cu}$, as well as increasing roughness, as shown in the Table 
(4). As for at $500^{\circ} \mathrm{C}$, we notice that the average roughness decreases when doping with an increase in the size of the grain, as shown in Table (5), because the diameters of the particles are close to each other than the diameters of the different particles (the diameters of the particles are similar) so the roughness is less in doping, but in the pure, the diameters of the particles are different, so the roughness is higher, and this is a guide to the shape of granularity cumulation distribution report in Figure (5).
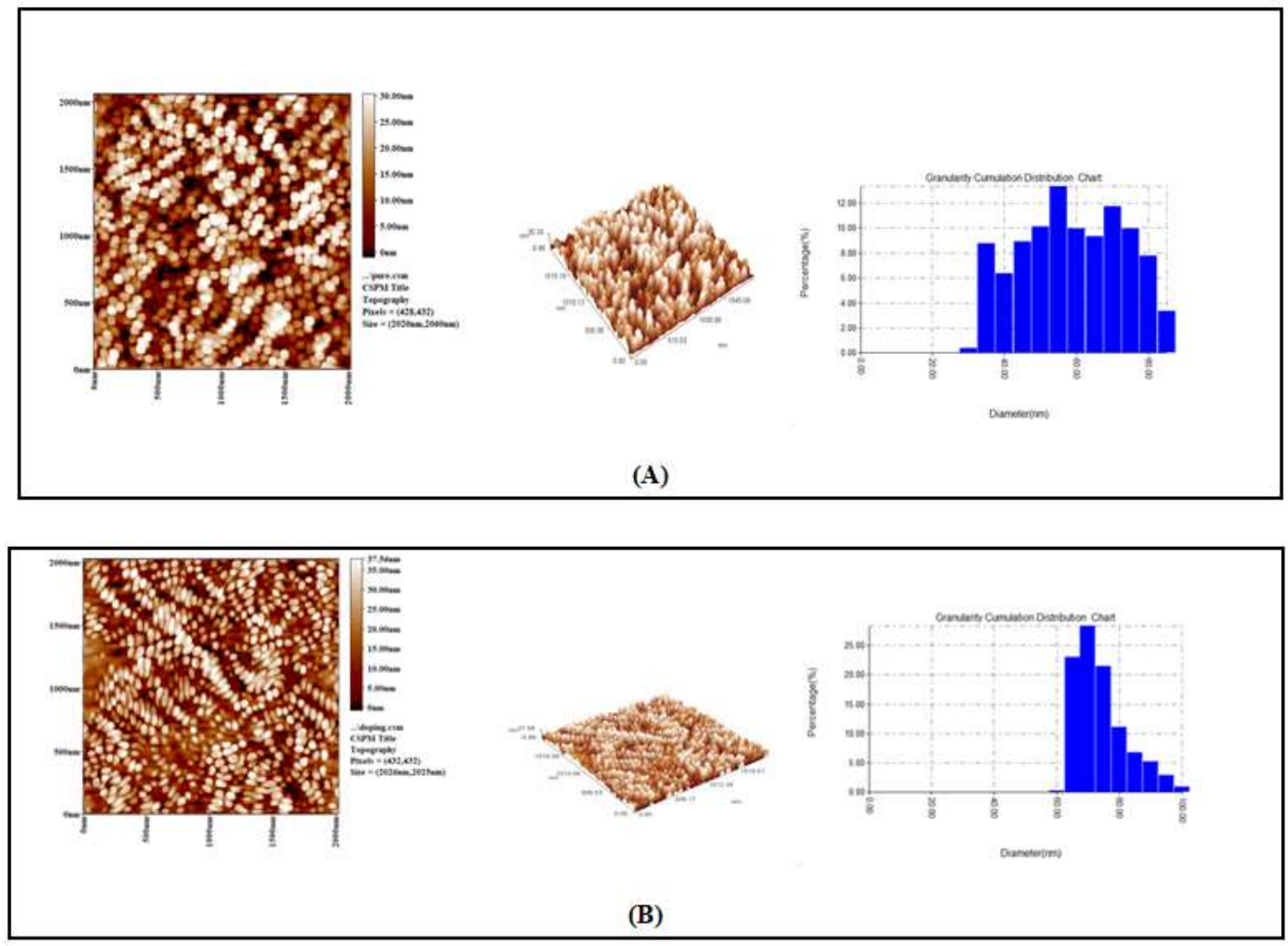

Figure (4). The AFM of (A): pure $\mathrm{SnO}_{2}$ Nano crystalline in 2D and 3D and Granularity Cumulation Distribution Report, and (B) $\mathrm{SnO}_{2}: \mathrm{Cu}$ in 2D and 3D and Granularity Cumulation Distribution Report, annealing at $300^{\circ} \mathrm{C}$.

Table (4). The grain size and roughness of pure $\mathrm{SnO}_{2}$ nanocrystalline and doped with $\mathrm{Cu}$, annealing at $300^{\circ} \mathrm{C}$.

\begin{tabular}{|c|c|c|}
\hline $\begin{array}{c}\text { Cu Doping } \\
\text { Concentration W\% }\end{array}$ & Grain Size (nm) & Roughness (nm) \\
\hline 0 & 56.36 & 7.99 \\
\hline 2 & 71.49 & 9.09 \\
\hline
\end{tabular}




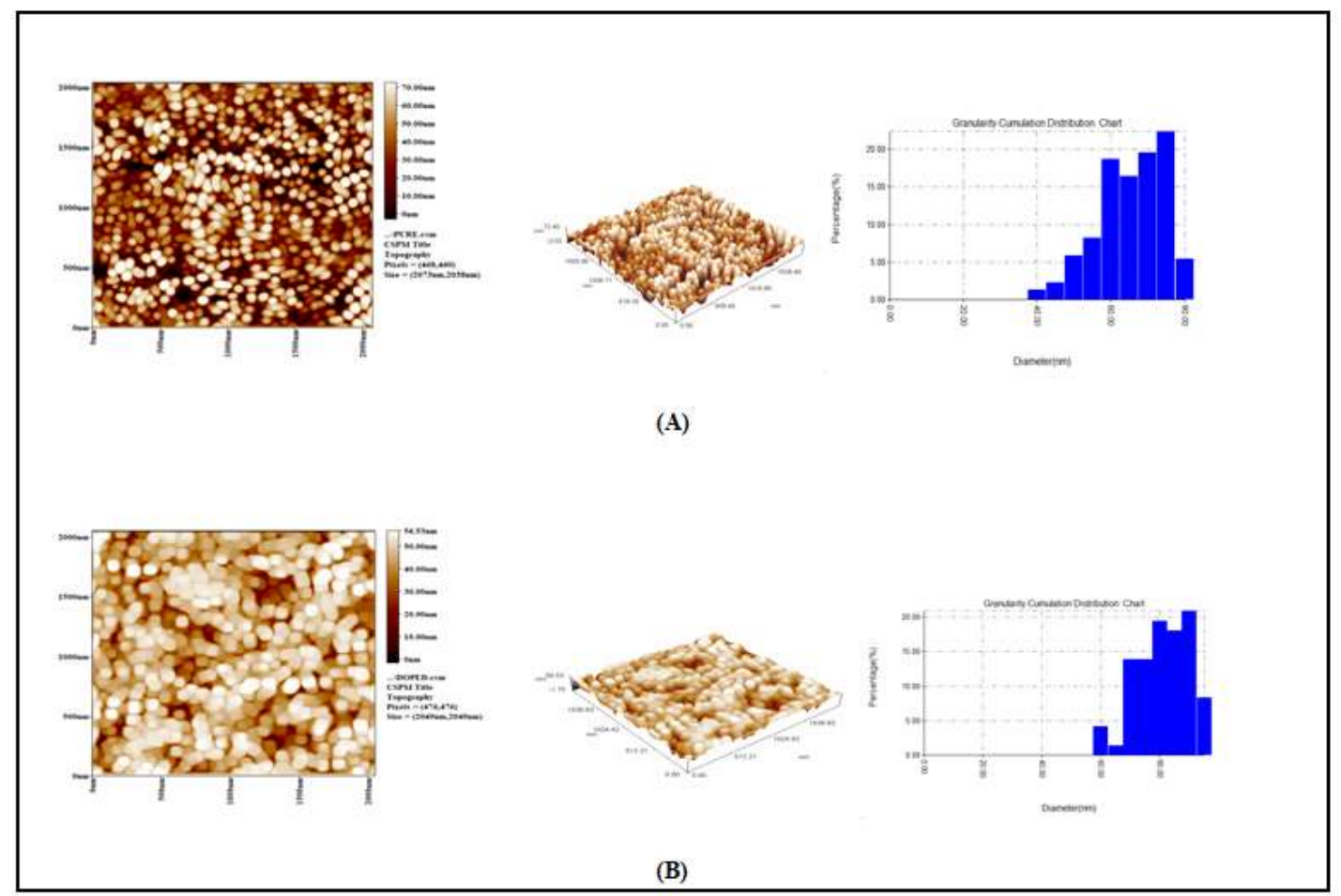

Figure (5). The AFM of (A) pure $\mathrm{SnO}_{2}$ Nano crystalline in 2D and 3D and Granularity Cumulation Distribution Report, and (B) $\mathrm{SnO}_{2}: \mathrm{Cu}$ in 2D and 3D and Granularity Cumulation Distribution Report, annealing at $500^{\circ} \mathrm{C}$.

Table (5). The grain size and roughness of pure $\mathrm{SnO}_{2}$ nanocrystalline and doped with $\mathrm{Cu}$, annealing at $500^{\circ} \mathrm{C}$.

\begin{tabular}{|c|c|c|}
\hline $\begin{array}{c}\text { Cu Doping } \\
\text { Concentration W\% }\end{array}$ & Grain Size (nm) & Roughness (nm) \\
\hline 0 & 63.15 & 17.4 \\
\hline 2 & 78.41 & 7.12 \\
\hline
\end{tabular}

Field Emission Scanning Electron Microscopy (FE-SEM) for Pure Nano crystalline of $\mathrm{SnO}_{2}$ and $\mathrm{Cu}$ Doped $\mathrm{SnO}_{2}$ Prepared by Spray Pyrolysis Method

By examining FE-SEM images of pure $\mathrm{SnO}_{2}$ and $\mathrm{SnO}_{2}: \mathrm{Cu}$ samples at $2 \%$ wt concentration and annealing at $300^{\circ} \mathrm{C}$ and $500^{\circ} \mathrm{C}$ as shown in Figure (6), the form and size of the grains can be determined. We observed that samples annealed at $300^{\circ} \mathrm{C}$ exhibit a size from $40 \mathrm{~nm}$ to $73 \mathrm{~nm}$ with a spherical shape, proving that $\mathrm{SnO}_{2}$ nanocrystalline has a nanoparticle domain [21]. The grain size decreasing as the annealing temperature increased. From $18.5 \mathrm{~nm}$ to $34.5 \mathrm{~nm}$ at $500^{\circ} \mathrm{C}$. The size of the grains reduces as the annealing temperature rises because the annealing process and the resulting deformation effect the recrystallization process, and that grain size increases at $300^{\circ} \mathrm{C}$ but reduces at $500^{\circ} \mathrm{C}$. Grain as well as hardness increase $[23,24]$. The thickness of the annealed nano-thin films is measured at $300^{\circ} \mathrm{C}$ and $500^{\circ} \mathrm{C}$, as shown in Figure (7), and it is found that the thickness of the thin films increases as the temperature rises. To enhance grain size, the thickness of the film was enhanced by raising the particle size and increasing the annealing temperature [25]. 


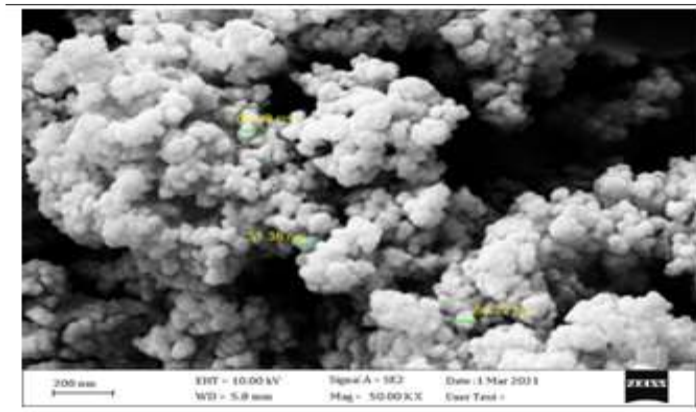

(A)

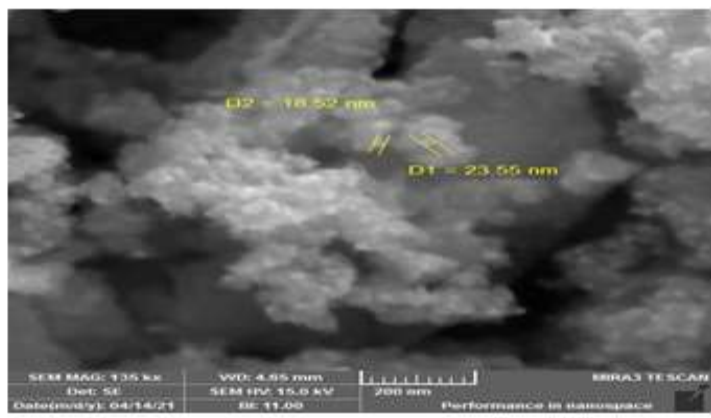

(C)

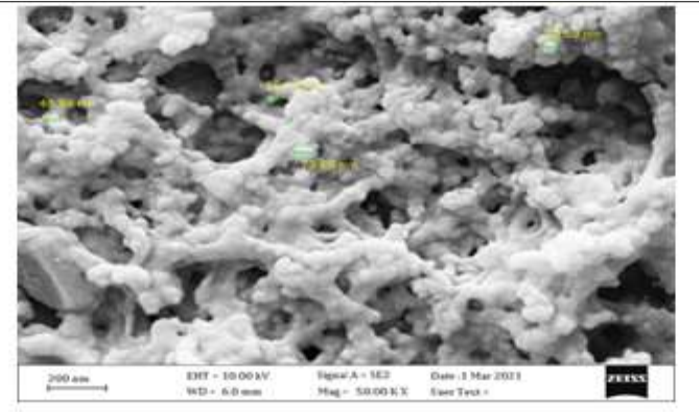

(B)

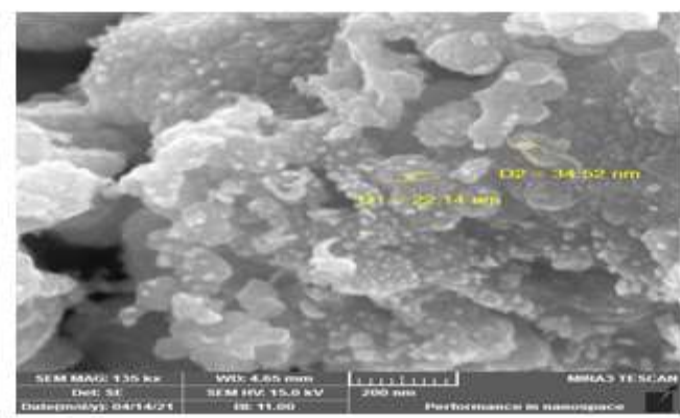

(D)

Figure (6). FE-SEM images of (A): pure $\mathrm{SnO}_{2}$ at $300^{\circ} \mathrm{C}$ annealing, (b): $2 \% \mathrm{SnO}_{2}: \mathrm{Cu}$ at $300^{\circ} \mathrm{C}$ annealing, (C): Pure $\mathrm{SnO}_{2}$ at $500^{\circ} \mathrm{C}$ annealing, and (D): $2 \% \mathrm{SnO}_{2}: \mathrm{Cu}$ at $500^{\circ} \mathrm{C}$ annealing.

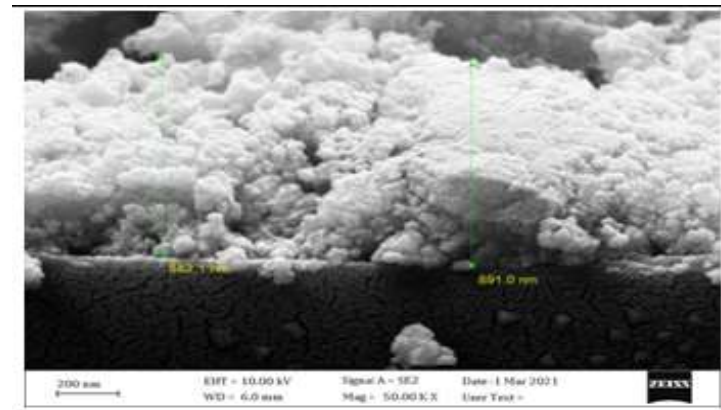

(A)

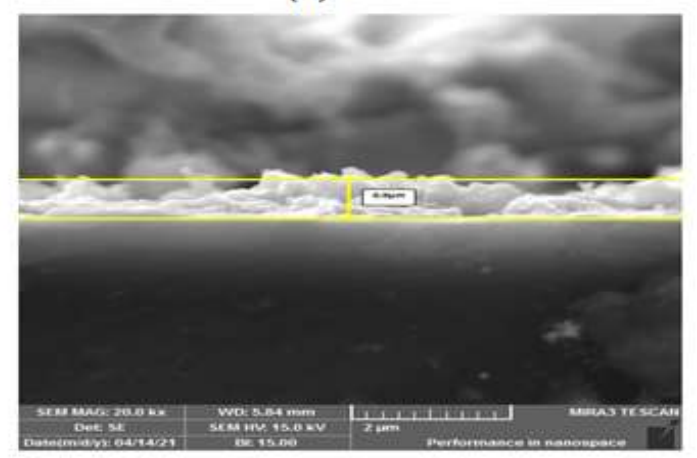

(C)

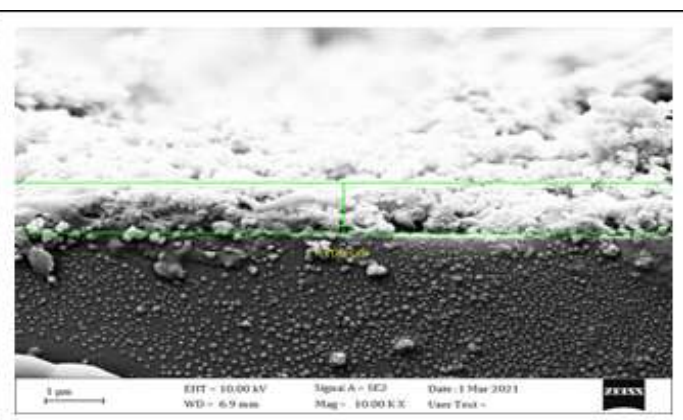

(B)

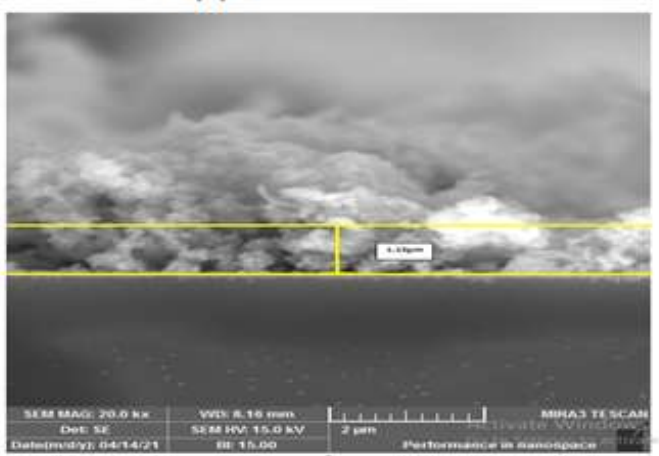

(D)

Figure (7). FE-SEM images of Cross Section (A): pure $\mathrm{SnO}_{2}$ at $300^{\circ} \mathrm{C}$ annealing, (b): $2 \% \mathrm{SnO}_{2}: \mathrm{Cu}$ at $300^{\circ} \mathrm{C}$ annealing, (C): pure $\mathrm{SnO}_{2}$ at $500^{\circ} \mathrm{C}$ annealing, and (D): $2 \% \mathrm{SnO}_{2}: \mathrm{Cu}$ at $500^{\circ} \mathrm{C}$ annealing. 


\section{Optical Measurements of Nanocrystalline Thin Films Prepared by Spray Pyrolysis Method}

Figure (8) shows the change in the absorbance spectrum as a function of wavelength and annealing temperature. The absorbance decreases as the annealing temperature increases, and with increasing the wavelength. This means that the incident photon is unable to excite the electron and transfer it from the valence to the conduction band. because its energy is less than the energy gap's value [26]. The number of layers was increased throughout the spraying process to achieve a uniform and homogeneous layer, resulting in a decrease in layer transparency due to an increase in grain size. The layer gets more opaque as the number of layers' increases (Ray et. al.) These results agree with AFM results shown elsewhere, which showed that the increasing doping by $2 \%$ results in grain size increase at $300^{\circ} \mathrm{C}$ and $500^{\circ} \mathrm{C}$ [27], that the transmittance of thin films when annealed at $300^{\circ} \mathrm{C}$ is higher than that at $500^{\circ} \mathrm{C}$ as shown in Figure (9), because the thickness of the annealed films at $500^{\circ} \mathrm{C}$ is greater than the thickness of the annealed films at $300^{\circ} \mathrm{C}$ and because the annealing worked to reduce crystal defects. As shown in Figure (10), the Extinction Coefficient $(\mathrm{K})$ is calculated for non-annealed and annealed thin films at $300^{\circ} \mathrm{C}$ and $500^{\circ} \mathrm{C}$. Extinction Coefficient varies with photon energy as the energy of the photon increases, and it is influenced by the thickness of the film, that the values of the coefficient of extinction generally increase s with the increase of the doping ratio due to the density. The levels formed by doping within the energy gap.

As shown in Figure (11), the refractive index (n) varies with the energy of a photon across a range of wavelengths. The wavelength ranges from $300 \mathrm{~nm}$ to $1100 \mathrm{~nm}$, with $\mathrm{n}$ decreasing with increasing film thickness and annealing temperature. This figure shows that the refractive index decreases with higher doping ratio.

Figure (12) shows the values of the energy gap for the permissible direct transmission of the pure and $2 \%$ wt doped $\mathrm{SnO}_{2}$ thin films. . The values of the energy gap decrease with doping and the reason for that is due to the fact that the doping leads to the addition of new sublevels near the valence band. The optical energy gap is critical in determining the feasibility of using Nano-thin films in cell manufacturing. The optical absorption can be utilized in solar cells (photovoltaic), display, and other applications, in which the film is transparent to radiation with an energy less than the energy gap $(\mathrm{h} v<\mathrm{Eg})$. And absorbing radiation with an energy greater than (hv>Eg), and there are many factors that influence the energy gap.

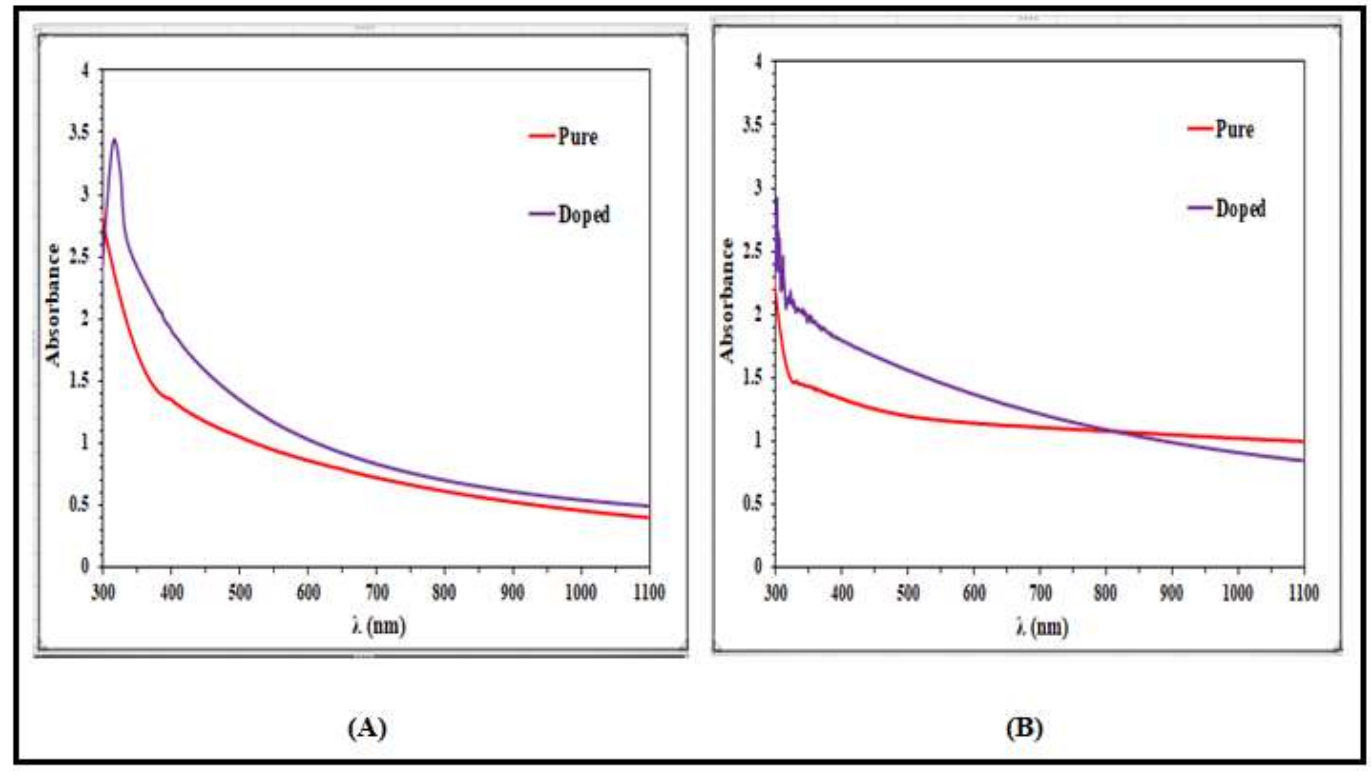

Figure (8). Shows the absorbance spectrum of (A): pure $\mathrm{SnO}_{2}$ nano crystalline \& $\mathrm{SnO}_{2}: \mathrm{Cu}$ annealed at $300^{\circ} \mathrm{C}$, and (B): pure $\mathrm{SnO}_{2}$ Nano crystalline \& $\mathrm{SnO}_{2}: \mathrm{Cu}$ annealed at $500^{\circ} \mathrm{C}$. 


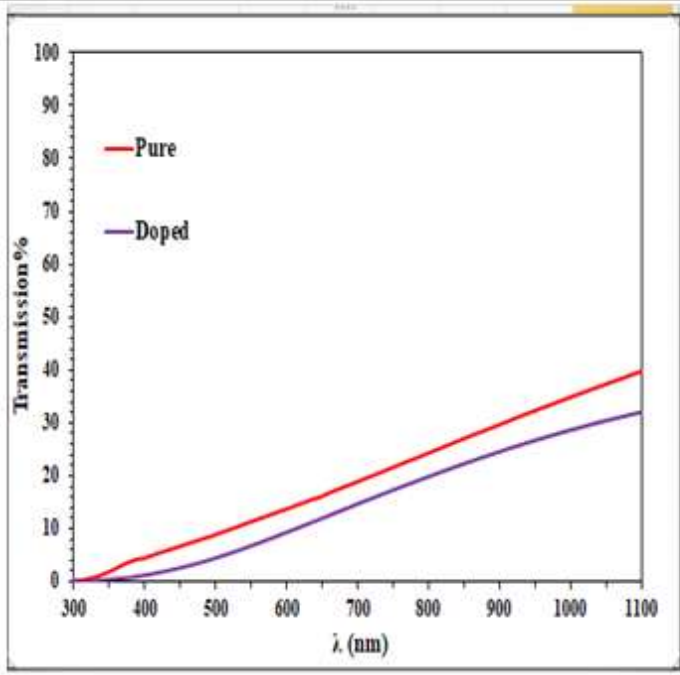

(A)

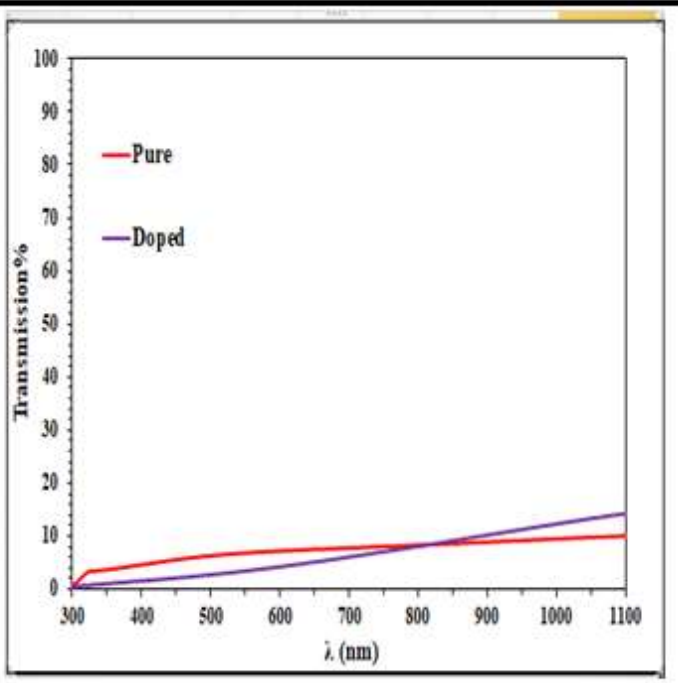

(B)

Figure (9). Shows the Transmittance spectrum of (A): pure $\mathrm{SnO}_{2}$ nanocrystalline \& $\mathrm{SnO} 2: \mathrm{Cu}$ annealed at $300^{\circ} \mathrm{C}$, and (B): pure $\mathrm{SnO}_{2} \mathrm{NPs}_{2} \mathrm{SnO}_{2}: \mathrm{Cu}$ annealed at $500^{\circ} \mathrm{C}$.

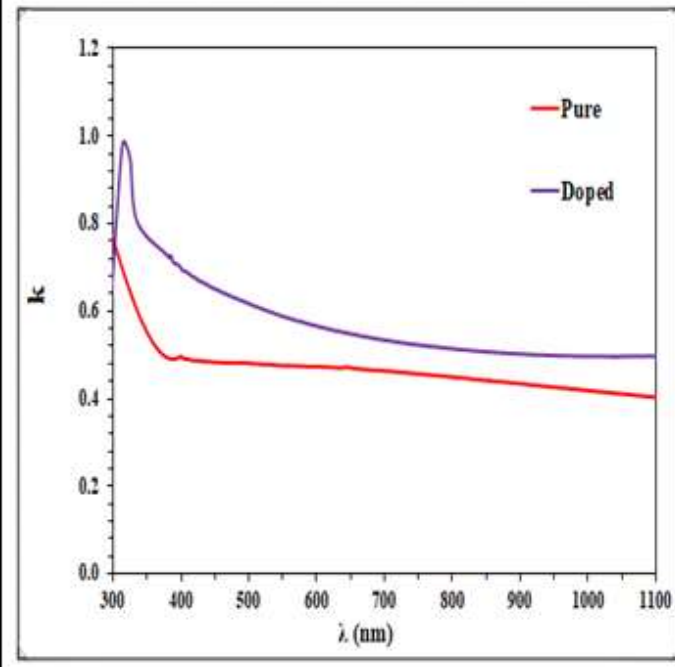

(A)

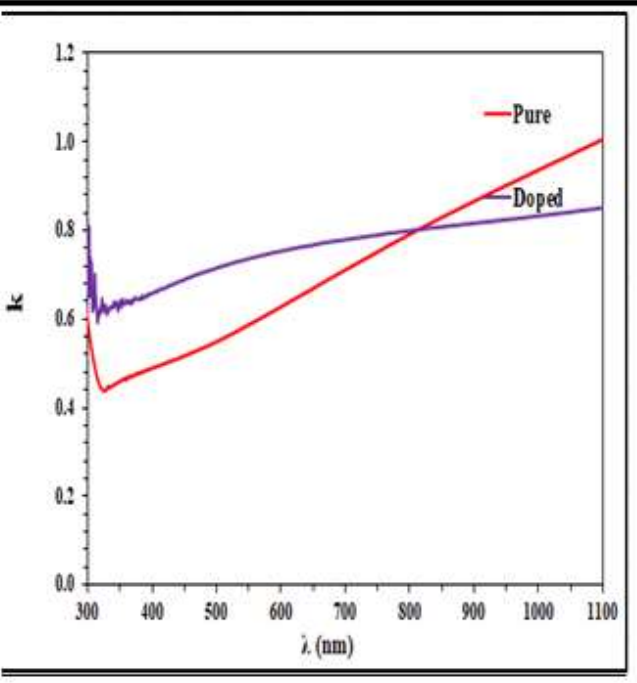

(B)

Figure (10). Shows the Extinction Coefficient of (A): pure $\mathrm{SnO}_{2}$ nanocrystalline $\& \mathrm{SnO}_{2}: \mathrm{Cu}$ annealed at $300^{\circ} \mathrm{C}$, and (B): pure $\mathrm{SnO}_{2}$ nanocrystalline \& $\mathrm{SnO}_{2}: \mathrm{Cu}$ annealed at $500^{\circ} \mathrm{C}$. 


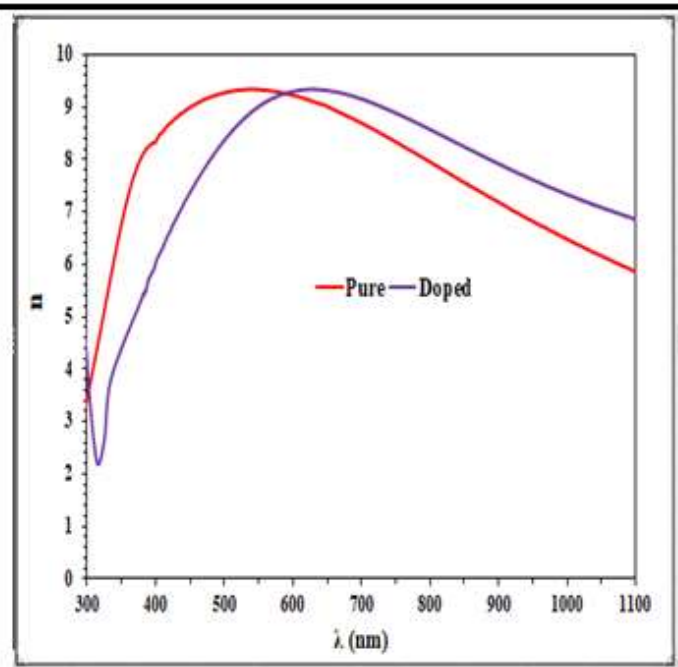

(A)

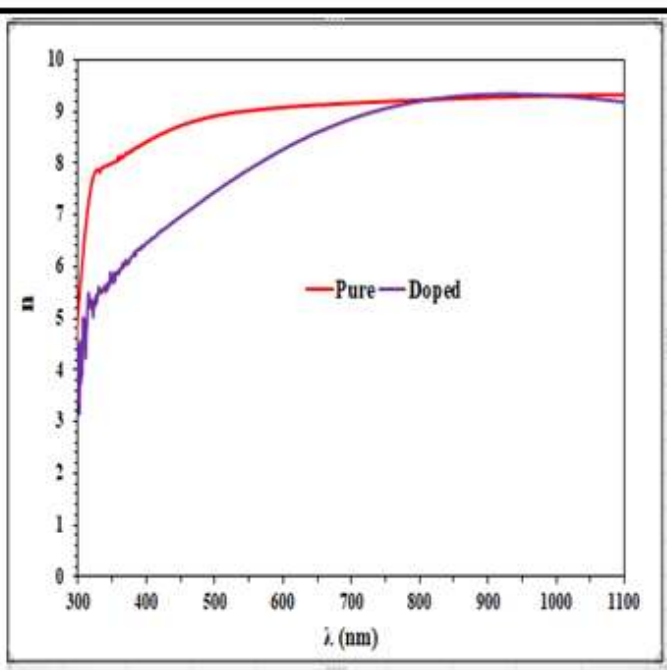

(B)

Figure (11). Shows The refractive index of (A): pure $\mathrm{SnO}_{2}$ nanocrystalline $\& \mathrm{SnO}_{2}: \mathrm{Cu}$ annealed at $300^{\circ} \mathrm{C}$, and (B): pure $\mathrm{SnO}_{2}$ nanocrystalline \& $\mathrm{SnO}_{2}: \mathrm{Cu}$ annealed at $500^{\circ} \mathrm{C}$.

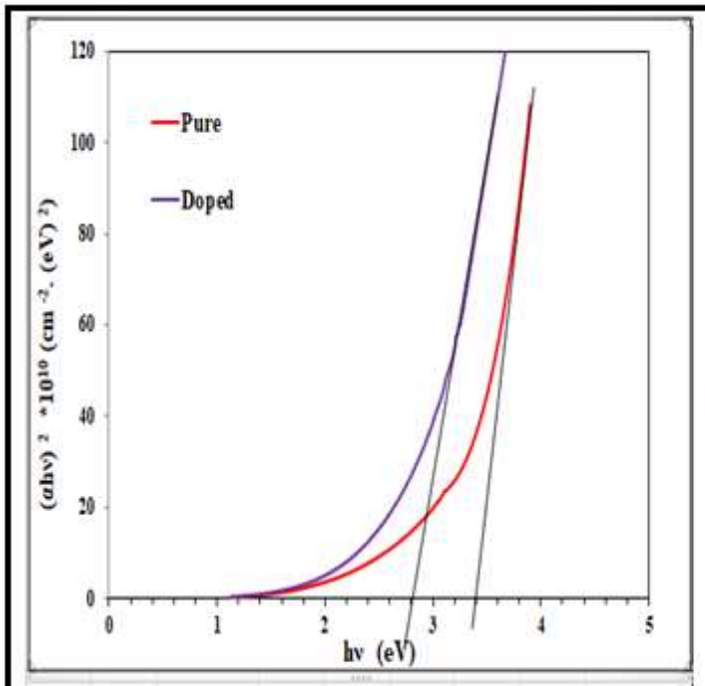

(A)

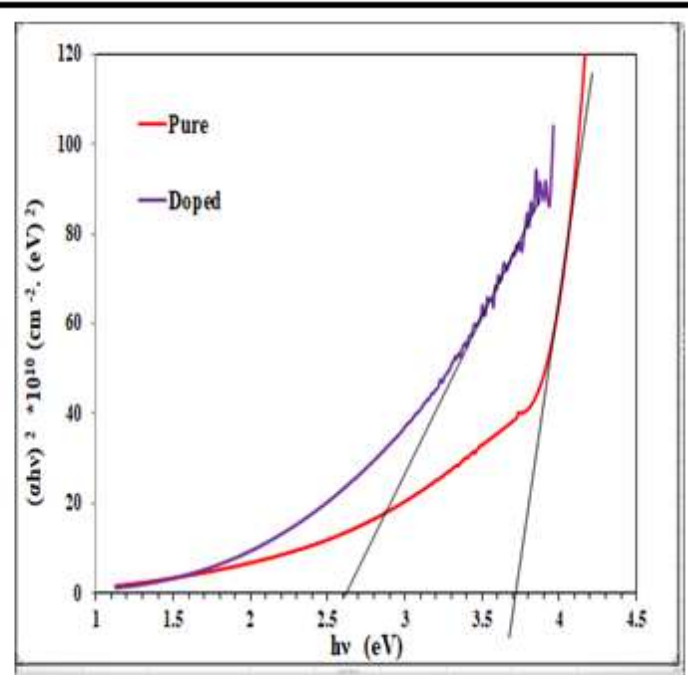

(B)

Figure (12). Shows optical energy gap of (A): pure $\mathrm{SnO}_{2}$ nanocrystalline \& $\mathrm{SnO}_{2}: \mathrm{Cu}$ annealed at $300^{\circ} \mathrm{C}$, and (B): pure $\mathrm{SnO}_{2}$ nanocrystalline \& $\mathrm{SnO}_{2}: \mathrm{Cu}$ annealed at $500^{\circ} \mathrm{C}$.

\section{Conclusions}

In this paper, thin films of tin oxide doped with $2 \%$ copper were fabricated by spray pyrolysis method, the XRD pattern showed that the $\mathrm{SnO} 2$ nanocrystals are tetragonal crystals and that the particle size was within the nanosize of the pure and doped substance. AFM and FESEM result It proved that the particles were spherical and of different sizes. As for the results of UV spectroscopy, it was found that the energy gap decreases with the increase of doping. As for the effect of the annealing temperature on the permeability and absorbance, it was 
shown that the permeability decreases with the increase in the annealing temperature, while the absorbance increases. From the compositional results, energy gap values, absorbance increase, roughness, and other results obtained, it is clear that the prepared samples can be used in different applications such as solar cells and gas sensors.

\section{References}

[1] M. J. Glover, E. Jones, K. L. Masconi, M. J. Sweeting, S. G. Thompson, and S. Collaborators, "Discrete event simulation for decision modeling in health care: lessons from abdominal aortic aneurysm screening," Med. Decis. Mak., vol. 38, no. 4, pp. 439-451, 2018.

[2] N. K. Abass, A. A. Baker, A. J. Cadhum, and N. A. Mahmood, "Structural and optical properties of SnS2: Cu thin films prepared by chemical spray pyrolysis," Baghdad Sci. J., vol. 7, no. 1, pp. 57-68, 2010.

[3] R. L. Mishra, S. K. Mishra, and S. G. Prakash, "optical and gas sensing characteristics of tin oxide nanocrystalline thin film.," J. Ovonic Res., vol. 5, no. 4, 2009.

[4] N. Sankara Subramanian, B. Santhi, S. Sundareswaran, and K. S. Venkatakrishnan, "Studies on spray deposited SnO2, Pd: SnO2 and F: SnO2 thin films for gas sensor applications," Synth. React. Inorganic, Met. Nano-Metal Chem., vol. 36, no. 1, pp. 131-135, 2006.

[5] P. M. Mwathe et al., "Influence of surface passivation on optical properties of spray pyrolysis deposited PdF: SnO2," 2014.

[6] B. V. Odari et al., "Optoelectronic properties of F-co-doped PTO thin films deposited by spray pyrolysis," Am. J. Mater. Sci., vol. 3, no. 4, pp. 91-99, 2013.

[7] A. E. Rakhshani, Y. Makdisi, and H. A. Ramazaniyan, "Electronic and optical properties of fluorine-doped tin oxide films," J. Appl. Phys., vol. 83, no. 2, pp. 1049-1057, 1998.

[8] P. M. Mwathe et al., "Effect of Annealing and Surface Passivation on Doped SnO2 Thin Films Prepared by Spray Pyrolysis Technique," Adv. Mater., vol. 4, no. 3, p. 51, 2015.

[9] P. M. Mwathe et al., "Surface passivation effect on CO2 sensitivity of spray pyrolysis deposited Pd-F: $\mathrm{SnO} 2$ thin film gas sensor," Adv. Mater., vol. 3, no. 5, pp. 38-44, 2014.

[10] F. de Moure-Flores et al., "SnO2: F thin films deposited by RF magnetron sputtering: effect of the $\mathrm{SnF} 2$ amount in the target on the physical properties," Rev. Mex. física, vol. 59, no. 4, pp. 335-338, 2013.

[11] S. M. Al-Delaimy and R. Basheer, "Annealing Effect on Structural and Optical Properties of SnO2 Thin Films,” J. Educ. Sci., vol. 21, no. 2, pp. 92-102, 2008.

[12] N. F. Habubi, Z. M. Abood, and A. N. Algamel, "Molar concentration Effects on the Optical and Structural Properties of nanostructural SnO2 Thin Films," Int. Lett. Chem. Phys. Astron., vol. 65, p. 81, 2016.

[13] V. K. Jain, P. Kumar, and Y. K. Vijay, "Preparation of nanostructure ZnO-SnO2 thin films for optoelectronic properties and post annealing influence," Int. J. Mater. Metall. Eng., vol. 6, no. 12, pp. 11921194, 2012.

[14] A. A. Yadav, E. U. Masumdar, A. V Moholkar, K. Y. Rajpure, and C. H. Bhosale, "Gas sensing of fluorine doped tin oxide thin films prepared by spray pyrolysis," J. Sens. Transducers, vol. 92, pp. 55-60, 2008.

[15] N. Jebbari, N. Kamoun, and R. Bennaceur, "Effect of SnCl4 concentration on F: SnO2, deposited by chemical spray pyrolysis," in the proceedings of International Renewable Energy Congress, 2010, pp. 276279.

[16] P. S. Patil, "Versatility of chemical spray pyrolysis technique," Mater. Chem. Phys., vol. 59, no. 3, pp. 185198, 1999. 
[17] E. Elangovan and K. Ramamurthi, "Optoelectronic properties of spray deposited SnO2: F thin films for window materials in solar cells,” J. Optoelectron. Adv. Mater., vol. 5, no. 1, pp. 45-54, 2003.

[18] P. Karthick, D. Vijayanarayanan, S. Suja, M. Sridharan, and K. Jeyadheepan, "Opto-electronic properties of fluorine doped tin oxide films deposited by nebulized spray pyrolysis method," Asian J Appl Sci, vol. 8, no. 4, pp. 259-268, 2015.

[19] Nachaithong T, Sikam P, Moontragoon P, Thongbai P, Kaewmaraya T, Ikonic Z. The study of optical and colossal dielectric properties of (Cu, Ga)-doped ZnO nanoparticles,” Eng Appl Sci Res., 2021;48(6):759-65.

[20] F. I. M. Fazli et al., "the effects of annealing temperature on properties of Aluminium-doped tin oxide (AL/SnO2), thin films deposited by spray pyrolysis deposited (SPD) method," 2006.

[21] Mohamed MB, Abdel-Kader MH, "Effect of annealed ZnS nanoparticles on the structural and optical properties of PVA polymer nanocomposite," Mater Chem Phys., vol. 241, pp. 122285, 2020.

[22] B. Yuliarto, G. GUMILARA, D. W. ZULHENDRIA, and N. L. W. Septiani, "Preparation of SnO 2 Thin Film Nanostructure for CO Gas Sensor Using Ultrasonic Spray Pyrolysis and Chemical Bath Deposition Technique.," Acta Phys. Pol. A., vol. 131, no. 3, 2017.

[23] C. W. Su, L. Lu, and M. O. Lai, "Recrystallization and grain growth of deformed magnesium alloy," Philos. Mag., vol. 88, no. 2, pp. 181-200, 2008.

[24] Pham V-T, Fang T-H, "Influences of grain size, alloy composition, and temperature on mechanical characteristics of Si100-xGex alloys during indentation process," Mater Sci Semicond Process., vol. 123, pp. 105568, 2021.

[25] S. A. Makee, A. A. M. Shehab, and A. M. Rehima, "Effect of Annealing Temperatures on the Structural and Optical Properties of $\mathrm{ZnO}$ and $\mathrm{ZnO}$ : Al Thin Films Prepared By Thermal Evaporation Technique," Ibn AL-Haitham J. Pure Appl. Sci., vol. 26, no. 3, pp. 153-160, 2017.

[26] P. Sagar, P. K. Shishodia, R. M. Mehra, H. Okada, A. Wakahara, and A. Yoshida, "Photoluminescence and absorption in sol-gel-derived ZnO films," J. Lumin., vol. 126, no. 2, pp. 800-806, 2007.

[27] S. Ray, P. S. Gupta, and G. Singh, "electrical and optical properties of sol-gel prepared pd-doped SnO2 thin films: effect of multiple layers and its use as room temperature methane gas sensor.," J. Ovonic Res., vol. 6, no. $2,2010$. 